\title{
THE HUMAN RESOURCE MANAGEMENT SERVICE IN HOTEL AND CATERING INDUSTRY
}

\author{
Dr. C K GOMATHY, Ms. Vitalam Karthya Reddy, Ms. Valeti Meghana, Ms. Maddali Varsha Reddy \\ Sri Chandrasekharendra Saraswathi Viswa Mahavidyalaya, Kanchipuram
}

\begin{abstract}
:
Human assets, or, to put it another way, human resources, are one of the most significant expenditures for most hospitality businesses. In most hotels, payroll is the single most expensive item, whereas, in restaurants and bars, it is frequently only second to material expenditures. Furthermore, human resources are frequently the first point of contact between a company and its customers. As a result, effective management of these human resources is critical to the enterprise's success. The hotel and catering industries have made significant contributions to this overall growth in living standards by providing critical and recreational services and employment and wealth development.Hotel development in any nation is a meticulous process that necessitates extensive planning before, during, and after construction, resulting in some hotels being unable to meet today's and tomorrow's ever-changing and increasing customer needs, including the fact that demand far outstrips supply, with major cities are experiencing shortages. Despite technological advancements within the catering business, the working circumstances of a huge number of industry employees have not kept pace with those experienced by working people elsewhere. The causes for the delayed pace of development in the industry's employment situation are several, including many owners and managers' reasonable reluctance to alter labor remuneration in response to industry advancements. Another factor might be that most trade union movements have limited sway in most sections of the business, especially since the majority of those employed in the industry not hoping to make a profession out of it. The working conditions of the industry's employees are deplorable for the most part. There are inherent disadvantages that cannot be avoided, such as working late hours and weekends. Other issues, on the other hand, can almost always be eliminated or decreased with deliberate managerial action. Staff reliance on tips, workers' misunderstanding of techniques of calculating compensation and the distribution of service charges, and management's reluctance to include employees in subjects that influence their working life are examples of such issues. As a result, management should devise a strategy for bringing out the best in these groups of undervalued employees.
\end{abstract}

Keywords: Generosity, Sociability, Encouragement, Expansion, Personnel, Inducement 


\section{INTRODUCTION:}

People have been traveling since the dawn of recorded history, and they have required shelter while doing so. As a result, some lodging in the form of inns small hotels, and bigger hospitality suites sprung up to accommodate these demands. As a result, hospitality is considered the world's second-oldest profession.However, in recent years, Nigeria's hosting of major international events such as the Common Wealth Heads of Government Meeting (CHOGM), All African Games, Carnivals, and meetings, which included visits by two American presidents and other presidents with their entourages, has resulted in the construction of several more hotels, particularly in the major cities.Since then, numerous significant improvements and changes have occurred in Nigeria, resulting in a relative increase in the level of life for the great majority of working people. Many reasons have contributed to these gains, including increased national productivity, better economic development, more enlightened management, and trade union demands. The hotel and catering industries have made significant contributions to this overall growth in living standards by providing critical and recreational services and employment and wealth development.

\section{SCOPE OF CATERING INDUSTRY:}

To that end, the purpose of this study is to evaluate the reasonableness of all entitlements owed or payable to the portion of the labor force that works in the hotel and catering business full-time or part-time. This investigation's goals are thus. To look at the reasonableness of extra benefits and rights that aren't included in the basic payment. Determine the extent to which compensation in this industry is comparable with the efforts of employees. To determine how similar this industry's pay and perks are to those in similar industries. To investigate the present industrial relations in the hotel under investigation and their impact on worker welfare.

\section{THE STUDY'S INITIAL CONTEXT:}

People have been traveling since the dawn of recorded history, and they have required shelter while doing so. As a result, some lodging in the form of inns and small hotels, as well as bigger hospitality suites, sprang up to accommodate these needs. As a result, hospitality is considered the world's second-oldest profession. Hotels, particularly the well-known names in the international hotel business, were virtually 
non-existent. The creation of several additional hotels, particularly in the major cities, has resulted from the visits of two American presidents and foreign presidents with their entourages. The hotel and catering industries have made significant contributions to this general growth in living standards by providing critical and recreational services, as well as employment and wealth development.

Hotel development in any country is a meticulous process that necessitates extensive planning before, during, and after construction. Despite technological advancements within the catering business, the working circumstances of a huge number of industry employees have not kept pace with those enjoyed by working people elsewhere. The causes for the delayed rate of development in the industry's employment situation are several, including many proprietors' and managers' understandable reluctance to alter labor remuneration in response to industry advancements. Another factor could be that most trade union movements have limited sway in most sections of the industry, especially since the majority of those employed in the industry are not looking to make a career out of it. The working conditions of the industry's employees are, for the most part, deplorable. There are inherent disadvantages that cannot be avoided, such as working late evenings and weekends. Other issues, on the other hand, can almost always be eliminated or decreased with deliberate managerial action. Staff reliance on tips, workers' ignorance of techniques of calculating compensation and the distribution of service charges, and management's reluctance to include employees in subjects that influence their working lives are examples of such issues. As a result, management should devise a strategy for bringing out the best in these groups of undervalued employees.

\section{PROBLEM STATEMENT:}

Expertise is predicted to be limited in a sector in Africa that appears to have been growing steadily over the years, which poses a concern. The study wants to look into these and other issues and give recommendations if necessary. The lack of experienced hands in this industry in the third world appears to be related to management's reluctance to train and hire capable people. Another issue is that most workers in the business have no clear outlets through which to express their concerns and grievances because management frequently suppresses unionization efforts.

The third issue is how workers' basic wages and perks are proportional to their commitment to work and efforts. Employers who are less responsive to changes in the economy in terms of adjusting pay and benefits packages in line with economic growth, as is the case in most developing countries today, are left 
with employees who are less committed to their jobs; their morale, and motivation to work have plummeted. We also have to deal with an environment in which employees are frequently kept in the dark about matters about which they have a right to know. For example, payment determination technique, promotion criterion (and so on), but such matters are depending on management's whims. This is a serious issue.

The final issue is that most individuals believe that positions in the business are the last resort that they can take if they cannot find a "better" job to do. As a result, young individuals who want to work in the hotel and catering industry are discouraged.

After identifying some of the issues, the goal of this research is to find potential solutions to some of them.

\section{WAGE AND SALARY REQUIREMENTS:}

Salaries and wages are paid by businesses to obtain the labor they need to operate. Apart from a wellarticulated system of determining basic pay rates, which is unusual in the hotel and catering industry, other considerations like tipping and service charges must be considered.

All of these factors, as well as the provision of meals and lodging, must be considered. Hotel payment systems are particularly problematic since they often consist of basic pay and subsidized room and food for employees, as well as gratuities, service charges, and fiddles, which are all names used to characterize various transactions by property staff outside of the hotel. A primary obligation of managers in wage administration is to decide how to distribute the money set aside for employee payment evenly across all employees. They may base their decision on what competitors pay the government, permitted rates, and other factors.

In many companies, in addition to regular salaries and wages, some employees can increase their "takehome" by earning additional compensation in various forms. These payments are primarily made to allow staff to share in the success of the company. By thanking individuals for their varied contributions to the project enterprise. 


\section{THE SYSTEM OF REWARDS:}

The goal of a successful reward system is to: Encourage qualified personnel to stay with the company. Obtaining wage parity for identical employment Providing incentives for further improvement and prizes for good performance in terms of performance. Being cost-effective in the sense that the system's advantages are realized without unnecessary expenditures is easy to explain, comprehend, control, and use.

In some places, the typical hotel manager appears to place such a high value on compensation as the primary incentive that he or she fails to appreciate the employee's accomplishments and sacrifices, which would ordinarily demand recognition outside of basic salary. Employees seek a reward for their efforts, as well as a challenge or motivation to work harder. The administration of pay and salaries must be evaluated while analyzing the reward system as being vital to employee motivation.

\section{SCOPE OF THE PROJECT:}

To that end, the purpose of this study is to evaluate the reasonableness of all entitlements owed or payable to the portion of the labor force that works in the hotel and catering business full-time or part-time. This investigation's goals are thus. To look at the reasonableness of extra benefits and rights that aren't included in the basic payment. Determine the extent to which compensation in this industry is comparable with the efforts of employees. To determine how similar this industry's pay and perks are to those in similar industries. To investigate the present industrial relations in the hotel under investigation and their impact on worker welfare.

\section{CONCLUSION:}

A variety of conclusions have been reached as a result of this research, including the following:

The following findings were reached:

$>$ That industry personnel is eager and determined to work for the greater benefit despite their inadequate pay packet and the fact that they work in a hotel

As a result, the bulk of them is unaffected by the entitlement package. 
b. That the industry's working conditions can be improved through management's efforts. In comparison to the effort put in by the employees, motivation is quite low.

\section{REFERENCES:}

1.Dr.C K Gomathy, Article: A Study on the recent Advancements in Online Surveying, International Journal of Emerging technologies and Innovative Research ( JETIR ) Volume 5 | Issue 11 | ISSN : 23495162, P.No:327-331, Nov-2018

2.Dr.C.K.Gomathy,C K Hemalatha, Article: A Study On Employee Safety And Health Management International Research Journal Of Engineering And Technology (Irjet)- Volume: 08 Issue: 04 | Apr 2021

3. Dr.C K Gomathy, Article: A Study on the Effect of Digital Literacy and information Management, IAETSD Journal For Advanced Research In Applied Sciences, Volume 7 Issue 3, P.No-51-57, ISSN NO: 2279-543X,Mar/2018

4. Dr.C K Gomathy, Article: An Effective Innovation Technology In Enhancing Teaching And Learning Of Knowledge Using Ict Methods, International Journal Of Contemporary Research In Computer Science And Technology (Ijcrcst) E-Issn: 2395-5325 Volume3, Issue 4,P.No-10-13, April ’2017

5.Dr.C K Gomathy, Article: Supply chain-Impact of importance and Technology in Software Release Management, International Journal of Scientific Research in Computer Science Engineering and Information Technology ( IJSRCSEIT ) Volume 3 | Issue 6 | ISSN : 2456-3307, P.No:1-4, July-2018

\section{AUTHOR DETAILS:}

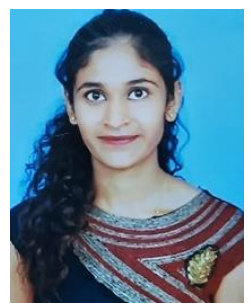

Vitalam Karthya Reddy, BE Computer Science, Sri Chandrasekarendra Saraswathi Viswa Maha Vidyalaya, Sri jayendra Saraswathi street, Enathur, Kanchipuram, Tamil Nadu, 631561, INDIA. 


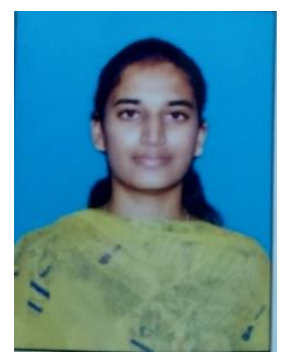

Valeti Meghana, BE Computer Science, Sri Chandrasekarendra Saraswathi Viswa Maha Vidyalaya, Sri jayendra Saraswathi street, Enathur, Kanchipuram, Tamil Nadu, 631561, INDIA.

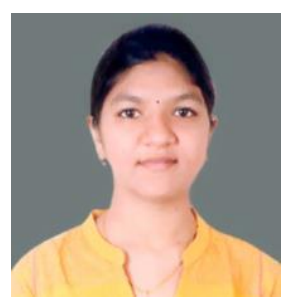

Maddali Varsha Reddy, BE Computer Science, Sri Chandrasekarendra Saraswathi Viswa Maha Vidyalaya, Sri jayendra Saraswathi street, Enathur, Kanchipuram, Tamil Nadu, 631561, INDIA.

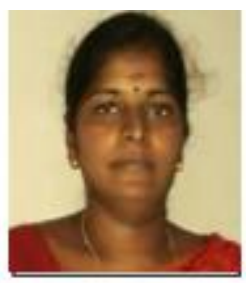

Dr. C.K.Gomathy, Assistant Professor [Computer Science and Engineering], Area of interest in Software Engineering, Web Services, Knowledge Management and IoT.

Sri Chandrasekharendra Saraswathi Viswa Maha Vidyalaya, Enathur, Kanchipuram, Tamil Nadu, 631561, INDIA. 